ljtihad, Jurnal Wacana Hukum Islam dan Kemanusiaan

Vol. 16, No. 1 (2016), pp. 105-129, doi : 10.18326/ijtihad.v16i1.105-129

\title{
Aplikasi metode dhariah dalam UU No. 35/2014 tentang Perubahan atas UU Nomor 23 Tahun 2002 tentang Perlindungan Anak
}

\author{
Usep Saepullah \\ Fakultas Syariah dan Hukum UIN Sunan Gunung Djati Bandung \\ E-mail: usepsaepullab72@gmail.com \\ DOI:10.18326/ijtihad.v16i1.105-129
}

Cases of violence in Indonesia based on data from the National Commission for Child Protection (KPA), In 2012, reports of violence against children rose to 2,637, with the presentation of 62 percent of the sexual violence include the category of sexual harassment as many as 122 cases, regarded as one indicator of the poor quality of child protection, The existence of children who have not been able to live independently, of course, is in desperate need of people as a shelter. The government has sought legal protection for children, so that children can get a guarantee for the continuity of life and living as part of human rights through the Act No. 23 of 2002 on Child Protection. The low quality of child protection in Indonesia, especially in sexual offenses and the amount of fines lot of criticism from various circles of society. The changes legislation relating relating to the protection of children from Law No. 23 of 2002 on the Protection of Children to Act No. 35 of 2014 about the amendment of Law No. 23 of 2002 on Child Protection contains a number of new perspectives (new paradigm) on the protection of children. One of the new paradigm it is the approach of preventing violence against children. In Islamic law approaches in child protection can be understood through the concept dhariah are sometimes prohibited form of preventive measures mentioned sadd al-dhariah, sometimes recommended even obliged called Fath al-dhariah. Methods dhariah in regulation Protection of Indonesian children develop in accordance with the development needs of the community through a new paradigm of Law No. 35 of 2014 on the Amendment of Act No. 23 of 2002 on Child Protection, on several things: the involvement of local governments in addition to the state, the government, society, families and the elderly, sexual crimes against children and restitution (compensation).

Kasus kekerasan yang terjadi di Indonesia berdasarkan data Komnas Perlindungan Anak (KPA), Tahun 2012, laporan kekerasan terhadap anak naik menjadi 2.637, dengan presentasi 62 persen merupakan kekerasan seksual diantaranya kategori pelecehan seksual sebanyak 122 kasus, dianggap sebagai salah satu indikator buruknya kualitas perlindungan anak. Keberadaan anak yang belum mampu untuk 
hidup mandiri tentunya sangat membutuhkan orang-orang sebagai tempat berlindung. Pemerintah telah berupaya memberikan perlindungan hukum pada anak, sehingga anak dapat memperoleh jaminan atas kelangsungan hidup dan penghidupannya sebagai bagian dari hak asasi manusia melalui UndangUndang No. 23 Tahun 2002 tentang Perlindungan Anak. Rendahnya kualitas perlindungan anak di Indonesia terutama pada kejahatan seksual dan besaran denda banyak menuai kritik dari berbagai kalangan masyarakat. Perubahan peraturan perundang-undangan yang berkaitan yang berkaitan dengan perlindungan anak dari UU No. 23 Tahun 2002 Tentang Perlindungan Anak ke UU No. 35 Tahun 2014 Tentang Perubahan atas UU No. 23 Tahun 2002 Tentang Perlindungan Anak memuat sejumlah cara pandang baru (new paradigm) tentang perlindungan anak. Salah satu paradigma baru itu adalah pendekatan pencegahan kekerasan terhadap anak. Dalam hukum Islam pendekatan dalam perlindungan anak dapat dipahami melalui konsep dhariah yang adakalanya dilarang berupa upaya preventif yang disebutkan sadd al-dhariah, adakalanya dianjurkan bahkan diwajibkan yang disebut fath al-dhariah. Metode dhariah pada regulasi Perlindungan anak Indonesia berkembang sesuai dengan perkembangan kebutuhan masyarakat melalui Paradigma baru Undang-Undang Nomor 35 Tahun 2014 tentang Perubahan Atas Undang-Undang Nomor 23 Tahun 2002 tentang Perlindungan Anak, pada beberapa hal yaitu keterlibatan pemerintah daerah selain negara, pemerintah, masyarakat, keluarga dan orang tua, kejahatan seksual terhadap anak dan restitusi (ganti rugi).

\section{Keywords: Protection of children; Islamic law; The child protection act; Restitution}

\section{Pendahuluan}

Anak adalah amanat Tuhan yang harus senantiasa dipelihara. Apapun statusnya, pada dirinya melekat harkat, martabat, dan hak-hak sebagai manusia yang harus dijunjung tinggi. Namun, pada kenyataannya betapa banyak anak yang terlantar, tidak mendapatkan pendidikan karena tidak mampu, bahkan menjadi korban tindak kekerasan. Kekerasan terhadap anak dalam setiap bulannya terdapat 30 kasus kekerasan yang diadukan oleh korbannya kepada lembaga konseling Yayasan Kesejahteraan Anak Indonesia. Dalam setiap bulannya terdapat 30 kasus kekerasan yang diadukan oleh korbannya kepada lembaga konseling Yayasan Kesejahteraan Anak Indonesia. Sebanyak 60\% merupakan korban kekerasan ringan, berupa kekerasan verbal atau caci maki, sedangkan 40\% sisanya mengalami kekerasan fisik hingga seksual. Kekerasan terhadap anak kini tidak hanya dari sisi psikologis/emosional, namun sudah bisa digolongkan pada penganiayaan, pelecehan seksual (Solihin, 2016), dan pencabulan, hingga pembunuhan.

Banyaknya kasus kekerasan yang terjadi di Indonesia dianggap sebagai salah satu indikator buruknya kualitas perlindungan anak. Keberadaan anak yang belum mampu untuk hidup mandiri tentunya sangat membutuhkan orang-orang sebagai tempat berlindung (Mansur, 
2007:122). Rendahnya kualitas perlindungan anak di Indonesia banyak menuai kritik dari berbagai kalangan masyarakat. Pemerintah telah berupaya memberikan perlindungan hukum pada anak, sehingga anak dapat memperoleh jaminan atas kelangsungan hidup dan penghidupannya sebagai bagian dari hak asasi manusia. Berdasarkan Undang-Undang No. 23 Tahun 2002 tentang Perlindungan Anak, yang berkewajiban dan bertanggung jawab terhadap penyelenggaraan perlindungan anak adalah negara, pemerintah, masyarakat, keluarga dan orang tua.

Untuk mengatasi kasus kekerasan, salah satu upaya dilakukan adalah mengangkat dan memberi perlindungan terhadap anak. Langkah ini sesuai dengan ajaran Islam yang menekankan saling tolong dalam kebaikan dan memelihara anak yatim. Fenomena ini tentu memerlukan perangkat hukum yang terkait dengan perlindungan dan pengangkatan anak. Undang-Undang Perlindungan dan Pengangkatan Anak pun dikeluarkan. Kemudian terus mengalami revisi dan penyempurnaan seiring dengan perkembangan waktu yang secara dinamis memunculkan banyak persoalan baru. Sejak disahkan, Undang-Undang Nomor 3 Tahun 2006 memberikan jawaban. Pengadilan agama telah diberikan kewenangan untuk menangani perkara permohonan pengangkatan anak berdasarkan hukum Islam.

H.A.R. Gibb dalam bukunya Muhammadanism, An Historical Survey, sebagaimana dikutip oleh Muhammad Muslehuddin (1991:58) bahwa hukum Islam memiliki jangkauan paling jauh dan alat yang efektif dalam membentuk tatanan sosial dalam kehidupan masyarakat Islam. Hoking, pakar hukum non-muslim dari Harvard University mengatakan bahwa sebenarnya dalam sistem hukum Islam itu sendiri terdapat kesiapan dan modal untuk berkembang dari dalam, tanpa memerlukan faktor-faktor dari luar dan berkeyakinan bahwa hukum Islam mempunyai teori secara lengkap dan teori-teori yang menjadi Sharat untuk disebut sebagai sistem hukum.(Mannan, 2009: 65) Pendekatan konsep sadd al-dhariah dan fat\#\} al-dhariah pada paradigma perlindungan anak sehingga perubahan hukum dan tujuan hukum Islam tercapai. Krisis beberapa peraturan perundang-undangan yang bertujuan melindungi hak-hak anak, di antaranya Undang-Undang Nomor 23 Tahun 2002 tentang Perlindungan Anak, membawa perubahan paradigma pada Undang-Undang Nomor 35 Tahun 2014 tentang Perubahan atas Undang-Undang Nomor 23 Tahun 2002 tentang Perlindungan Anak. 
ljtihad, Jurnal Wacana Hukum Islam dan Kemanusiaan, Volume 16, №. 1, Juni 2016: 105-129

Dari latar belakang tersebut dapat dirumuskan bahwa, eksistensi anak sebagai pelanjut pengembangan misi agama dan misi negara perlu dikawal dengan penegakan aturan yang melindunginya, sebab anak-anak termasuk kelompok lemah dan rawan dari perlakuan eksploitatif kaum dewasa. Oleh karena itu, pengembangan pemikiran hukum, formal dan non formal, harus turut mempertimbangkan ketercapaian perlindungan anak.

Pendekatan konsep dhariah (sadd al-dhariah dan fath al-dhariah) pada paradigma perlindungan anak merupakan upaya memahami aspek perubahan hukum islam terhadap perubahan paradigma pada Undang-Undang Nomor 35 Tahun 2014 tentang Perubahan Atas Undang-Undang Nomor 23 Tahun 2002 tentang Perlindungan Anak. Merupakan upaya menyelesaikan Krisis beberapa peraturan perundang-undangan yang bertujuan melindungi hak-hak anak, di antaranya Undang-Undang Nomor 23 Tahun 2002 tentang Perlindungan Anak.

Masalah tersebut dapat diidentifikasi dengan memahami tujuan penelitian tentang, Pendekatan sadd al-dhariah pada UU RI Nomor 23 Tahun 2002 tentang Perlindungan Anak dan paradigma baru hukum perlindungan anak pasca perubahan undang-undang perlindungan anak.

Adapun kegunaan Penelitian secara teoritis, Memperkaya khazanah ilmu keislaman, khususnya ilmu hukum Islam yang berkaitan dengan Perlindungan anak (Hadāanab); Memperkaya hasil-hasil penelitian sebelumnya yang berkaitan dengan konsep perlindungan anak dalam hukum Islam dan hukum positif di Indonesia, serta menjadi bahan kajian

penelitian selanjutnya. Secara Praktis, Meningkatkan wawasan dan pengetahuan tentang konsep dan prinsip-prinsip perlindungan anak menurut hukum Islam dan hukum positif; Menjadi salah satu bahan referensi bagi para praktisi hukum Islam dalam menangani kasus hukum yang berkaitan dengan perlindungan anak di Indonesia; Menjadi salah satu bahan pertimbangan para pemegang kebijakan dalam merancang dan menetapkan kebijakan politik yang berkaitan dengan perlindungan anak di Indonesia.

\section{Dhariah sebagai metode istinbat hukum}

Metode penetapan hukum yang dikembangkan para ulama di antaranya adalah dhariah. Metode sadd al-dhariah merupakan upaya preventif agar tidak terjadi sesuatu yang 
menimbulkan dampak negatif. Satu tujuan hukum Islam adalah untuk mewujudkan kemashlahatan dan menghindari kerusakan (mafsadab). Jika suatu perbuatan yang belum dilakukan diduga keras akan menimbulkan kerusakan (mafsadah), maka dilaranglah hal-hal yang mengarahkan kepada perbuatan tersebut. Metode hukum inilah yang kemudian dikenal dengan sadd al-dhariah. Sebaliknya, jika suatu perbuatan diduga kuat akan menjadi sarana terjadinya perbuatan lain yang baik, maka diperintahkanlah perbuatan yang menjadi sarana tersebut. Hal inilah yang kemudian dikenal dengan istilah fat al-dhariah.

Sadd al-dhariah (سد الذريعة) merupakan bentuk frase (idâfah) yang terdiri dari dua kata,

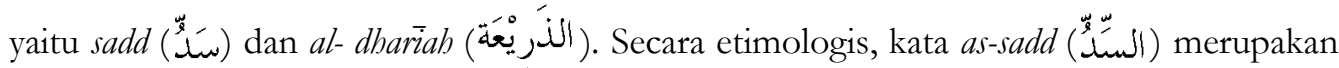

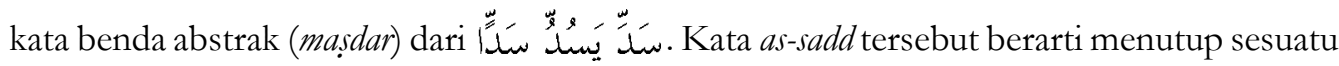
yang cacat atau rusak dan menimbun lobang (Ibn Manẓūr,juz III. t.t.:207). Sedangkan aldhariah (النَّريعِ merupakan kata benda (isim) bentuk tunggal yang ierarti jalan, sarana (wasilah) (Ibn Manẓūr, juz VIII. t.t.:93) dan sebab terjadinya sesuatu (al-Zabidi, Juz I; 512). Bentuk

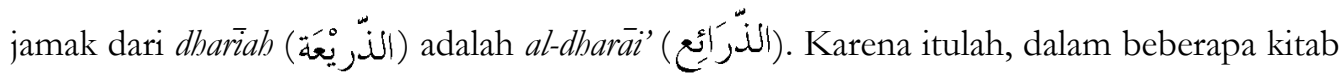
usul fikih, seperti Tanqī al-Fuṣū fi 'Ulum al-Ușūl karya al-Qarafi, istilah yang digunakan adalah sadd al-dharäi' (al-Qarafi,t.th.).

Al-dhariah menurut Ibn al-A'rabi, kata al-dhariah kemudian digunakan sebagai metafora terhadap segala sesuatu yang mendekatkan kepada sesuatu yang lain (Ibn Manẓūr, juz VIII. t.th.:93). Al-Qarafi menyatakan bahwa sadd al-dhariah bermakna memotong jalan kerusakan (mafsadah) sebagai cara untuk menghindari kerusakan tersebut. Meski suatu perbuatan bebas dari unsur kerusakan (mafsadab), namun jika perbuatan itu merupakan jalan atau sarana terjadi suatu kerusakan (mafsadab), maka kita harus mencegah perbuatan tersebut. Dengan ungkapan yang senada, menurut al-Shaukani (1994:295), al-dhariah adalah masalah yang pada lahirnya dibolehkan namun akan mengantarkan kepada perbuatan yang dilarang (al-mahžur).

Al-Shathibi (t.t.: Juz III, 257-258) dalam karyanya al-Muwāfaqāt, menyatakan bahwa sadd al-dhariah adalah menolak sesuatu yang boleh (jaiz) agar tidak mengantarkan kepada sesuatu yang dilarang (mamnū'). Menurut Mukhtar Yahya dan Fatchurrahman (1986:347) sadd aldhariah adalah meniadakan atau menutup jalan yang menuju kepada perbuatan yang terlarang. 
ljtihad, Jurnal Wacana Hukum Islam dan Kemanusiaan, Volume 16, №. 1, Juni 2016: 105-129

Sedangkan menurut Ibnu al-Qayyim al-Jauziyyah (1996: Juz II, 103), jalan atau perantara tersebut bisa berbentuk sesuatu yang dilarang maupun yang dibolehkan.

Secara umum berbagai pandangan ulama tentang sadd al-dhariah dapat diklasifikasikan dalam tiga kelompok; Kelompok pertama, yang menerima sepenuhnya sebagai metode dalam menetapkan hukum, adalah mazhab Maliki dan mazhab Hambali. Para ulama di kalangan Mazhab Maliki bahkan mengembangkan metode ini dalam berbagai pembahasan fikih dan ushul fikih mereka sehingga bisa diterapkan lebih luas. Imam al-Qarafi (w. 684 H), misalnya, mengembangkan metode ini dalam karyanya Anwär al-Burüq fi Anwär al-Furüq. Begitu pula Imam al-Shatibi (w. $790 \mathrm{H}$ ) yang menguraikan tentang metode ini dalam kitabnya alMuwāfaqūt.

Kelompok kedua, yang tidak menerima sepenuhnya sebagai metode dalam menetapkan hukum, adalah mazhab Hanafi dan mazhab Shafi'i. Dengan kata lain, kelompok ini menolak sadd al-dhariah sebagai metode istinbat $\}$ pada kasus tertentu, namun menggunakannya pada kasus-kasus yang lain. Contoh kasus penggunaan sadd al-dhariah oleh mazhab Hanafi adalah tentang wanita yang masih dalam iddah karena ditinggal mati suami. Si wanita dilarang untuk berhias, menggunakan wewangian, celak mata, pacar, dan pakaian yang mencolok. Merupakan sadd al-dhariah agar tidak terjadi perbuatan yang diharamkan, yaitu pernikahan perempuan dalam keadaan iddah. (al-Shafi'i:t.th., 249).

Kelompok ketiga, yang menolak sepenuhnya sebagai metode dalam menetapkan hukum, adalah mazhab 'ahiri. Hal ini sesuai dengan prinsip mereka yang hanya menetapkan hukum berdasarkan makna tekstual (žăhir al-lafঞa). Sementara sadd al-dhariah adalah hasil penalaran terhadap sesuatu perbuatan yang masih dalam tingkatan dugaan, meskipun sudah sampai tingkatan dugaan yang kuat. Konsep sadd al-dhariah bagi mereka adalah semata-mata produk akal dan tidak berdasarkan pada nas secara langsung.

Ibnu Hazm (994-1064 M), salah satu tokoh ulama dari mazhab 'ahiri, bahkan menulis satu pembahasan khusus untuk menolak metode sadd al-dhariah dalam kitabnya al-Aḥkam $\bar{f}$ Usūl al-Ị̣kām. Ia menempatkan sub pembahasan tentang penolakannya terhadap sadd aldhariah dalam pembahasan tentang al-ihtiyat (kehati-hatian dalam beragama). Sadd al-dhariah lebih merupakan anjuran untuk bersikap warga dan menjaga kehormatan agama dan jiwa agar tidak tergelincir pada hal-hal yang dilarang. Konsep sadd al-dhariah tidak bisa berfungsi 
untuk menetapkan boleh atau tidak boleh sesuatu. Pelarangan atau pembolehan hanya bisa ditetapkan berdasarkan nas dan ijma’ (qat’i) (Ibn Hazm, 1998:179-189).

Terkait dengan kedudukan sadd al-dhariah, Elliwarti Maliki, seorang doktor wanita pertama asal Indonesia lulusan al-Azhar, Kairo, menganggap bahwa sadd al-dhariah merupakan metode istinbāt (penalaran) hukum yang mengakibatkan kecenderungan sikap defensif (mempertahankan diri) di kalangan umat Islam. Pada gilirannya sadd al-dhariah cenderung menjadi bias gender, dan menghasilkan pandangan ulama yang melarang wanita untuk berkiprah lebih luas di masyarakat, seperti larangan wanita ke luar rumah demi mencegah bercampur dengan lelaki yang bukan mahram.

Adapun dasar Hukum Sadd al-dhariah, al-Quran dalam surat al-An'am, 6: 108:

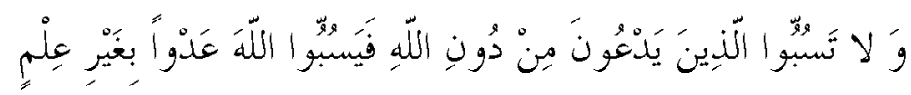

"Dan janganlah kamu memaki sembahan-sembahan yang mereka sembah selain Allah, Karena mereka nanti akan memaki Allah dengan melampaui batas tanpa pengetahuan... (QS. al-An’am, 6: 108).

Pada ayat di atas, mencaci maki tuhan atau sembahan agama lain adalah al-dhariah yang akan menimbulkan adanya sesuatu mafsadah yang dilarang, yaitu mencaci maki Tuhan. Sesuai dengan teori psikologi mechanism defense, orang yang Tuhannya dicaci kemungkinan akan membalas mencaci Tuhan yang diyakini oleh orang sebelumnya mencaci. Karena itulah, sebelum balasan caci maki itu terjadi, maka larangan mencaci maki tuhan agama lain merupakan tindakan preventif (sadd al-dhariah).

Adapun dalam Al-Sunnah dijelaskan ;

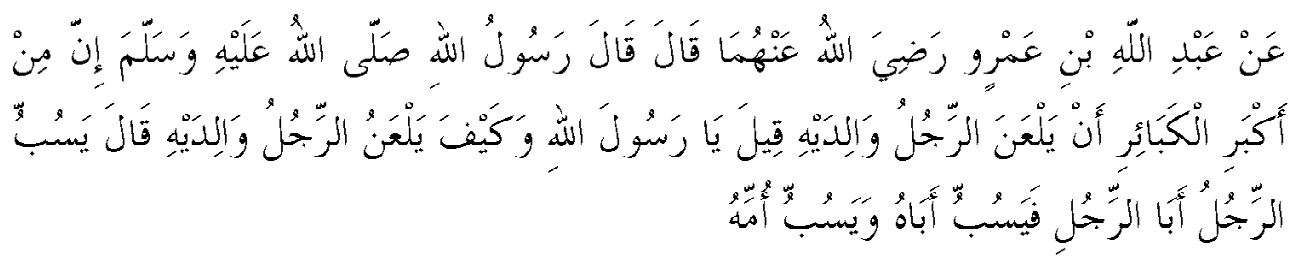

Dari Abdullab bin Amr RA, ia berkata, Rasulullah $S A W$ bersabda: "Termasuk di antara dosa besar seorang lelaki melaknat kedua orang tuanya." Beliau kemudian ditanya, "Bagaimana caranya seorang lelaki melaknat kedua orang tuanya?" Beliau menjawab, "Seorang lelaki mencaci maki ayah orang lain, kemudian orang yang dicaci itu pun membalas mencaci maki ayah dan ibu tua lelaki tersebut (Bukhari, 1987:2289). 
ljtihad, Jurnal Wacana Hukum Islam dan Kemanusiaan, Volume 16, №. 1, Juni 2016: 105-129

Hadist ini dijadikan oleh Imam Shathibi sebagai salah satu dasar hukum bagi konsep sadd al-dhariah. Berdasarkan hadits tersebut, menurut tokoh ahli fikih dari Spanyol itu, dugaan (dhann) bisa digunakan sebagai dasar untuk penetapan hukum dalam konteks sadd al- aldhariah (Al-Syatibi, juz II, 360).

Kaedah fikih yang bisa dijadikan dasar penggunaan sadd al-dhariah adalah

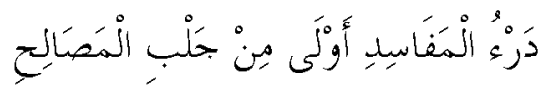

Menolak keburukan (mafsadab) lebih diutamakan daripada meraib kebaikan (mas \}lab\}ah) (alSuyuthi, t.th.:176).

Kaedah ini merupakan kaedah asasi yang bisa mencakup masalah-masalah turunan di bawahnya. Sadd al-dhariah pun bisa disandarkan kepadanya. Hal ini bisa dipahami, karena dalam sadd al-dhariah terdapat unsur mafsadah yang harus dihindari.

Ibnu al-Qayyim menjelaskan dalam kitab Aläm al-Muwaqīn: "Ketika Allah melarang suatu hal, maka Allah pun akan melarang dan mencegah segala jalan dan perantara yang bisa mengantarkan kepadanya. Hal itu untuk menguatkan dan menegaskan pelarangan tersebut. Namun jika Allah membolehkan segala jalan dan perantara tersebut, tentu hal ini bertolak belakang dengan pelarangan yang telah ditetapkan” (Ibn Qayyim, II: 103).

Dilihat dari aspek akibat yang timbulkan, Ibnu al-Qayyim mengklasifikasikan al-dhariah menjadi empat macam, yaitu: 1) Suatu perbuatan yang memang pada dasarnya pasti menimbulkan kerusakan (mafsadab); 2) Suatu perbuatan yang pada dasarnya diperbolehkan atau dianjurkan (mustahab), namun secara sengaja dijadikan sebagai perantara untuk terjadi sesuatu keburukan (mafsadab). Misalnya menikahi perempuan yang sudah ditalak tiga agar sang perempuan boleh dikawini (al-tablit); 3) Suatu perbuatan yang pada dasarnya diperbolehkan namun tidak disengaja untuk menimbulkan suatu keburukan (mafsadab), dan pada umumnya keburukan itu tetap terjadi meskipun tidak disengaja. Keburukan (mafsadah) yang kemungkinan terjadi tersebut lebih besar akibatnya daripada kebaikan (mashlahah) yang diraih. Contohnya adalah mencaci maki berhala yang disembah oleh orang-orang mushrik; 4) Suatu perbuatan yang pada dasarnya diperbolehkan namun terkadang bisa menimbulkan keburukan (mafsadah). Kebaikan yang ditimbulkan lebih besar akibatnya daripada keburukannya. Misalnya, melihat perempuan yang sedang dipinang dan mengkritik pemimpin 
yang lalim.

Fatḥ al-dhariah adalah kebalikan dari sadd al-dhariah adalah fatḥ al-dhariah. Hal ini karena titik tolak yang digunakan adalah al-dhariah. Dalam mazhab Maliki dan Hambali, al-dhariah memang ada yang dilarang dan ada yang dianjurkan. Hal ini diungkapkan oleh al-Qarafi yang dianggap berasal mewakili mazhab Maliki dan Ibnu al-Qayyim al-Jauzi yang dianggap mewakili mazhab Hambali. Al-dhariah adakalanya dilarang sehingga pelarangan itu disebut sadd al-dhariah; adakalanya dianjurkan atau diperintahkan sehingga anjuran atau perintah itu disebut fath al-dhariah (al-Qarafi, Juz III:36).

Secara terminologis, bisa dipahami bahwa fatḥ al-dhariah adalah menetapkan hukum atas suatu perbuatan tertentu yang pada dasarnya diperbolehkan, baik dalam bentuk membolehkan (ibāhah), menganjurkan (istihāb), maupun mewajibkan (ijäb) karena perbuatan tersebut bisa menjadi sarana terjadinya perbuatan lain yang memang telah dianjurkan atau diperintahkan.

Fatḥ al-dhariah tercermin pada contoh mengerjakan shalat Jum'at adalah wajib, maka wajib pula berusaha untuk sampai ke masjid dan meninggalkan perbuatan lain. Contoh lain adalah jika menuntut ilmu adalah sesuatu yang diwajibkan, maka wajib pula segala hal yang menjadi sarana untuk tercapai usaha menuntut ilmu, seperti membangun sekolah dan menyusun anggaran pendidikan yang memadai. Namun yang juga harus digarisbawahi adalah bahwa betapapun al-dhariah (sarana) lebih rendah tingkatannya daripada perbuatan yang menjadi tujuannya. Pelaksanaan atau pelarangan suatu sarana tergantung pada tingkat keutamaan perbuatan yang menjadi tujuannya (al-Qarafi, Juz III:46).

Pembahasan tentang fatḥ al-dhariah tidak mendapat porsi yang banyak di kalangan ahli Ușūl al-Fiqh. Hal itu karena fath al-dhariah hanyalah hasil pengembangan dari konsep sadd aldhariah. Sementara sadd al-dhariah sendiri tidak disepakati oleh seluruh ulama sebagai metode istinbäth bukm (penalaran hukum). Hal itu karena bagi sebagian mereka, terutama di kalangan ulama Shafi'iyyah (Al-Zarkashi, Juz VII: 358) masalah sadd al-dhariah dan fatḥ al-dhariah masuk dalam bab penerapan kaedah:

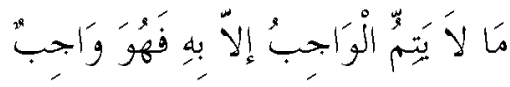

Jika suatu kewajiban tidak sempurna dilaksanakan tanpa suatu hal tertentu, maka hal tertentu itu pun wajib pula untuk dilaksanakan. 
ljtihad, Jurnal Wacana Hukum Islam dan Kemanusiaan, Volume 16, №. 1, Juni 2016: 105-129

Cara Menentukan al-dhariah, guna menentukan apakah suatu perbuatan dilarang atau tidak, karena ia bisa menjadi sarana (al-dhariah) terjadinya suatu perbuatan lain yang dilarang, maka secara umum hal itu bisa dilihat dari dua hal (Zuhaili, 1986:879-880), yaitu: 1) Motif atau tujuan yang mendorong seseorang untuk melaksanakan suatu perbuatan, apakah perbuatan itu akan berdampak kepada sesuatu yang dihalalkan atau diharamkan; 2) Akibat yang terjadi dari perbuatan, tanpa harus melihat kepada motif dan niat si pelaku. Jika akibat atau dampak yang sering kali terjadi dari suatu perbuatan adalah sesuatu yang dilarang atau mafsadah, maka perbuatan itu harus dicegah. Misalnya, berdasarkan beberapa peristiwa yang sebelumnya terjadi, seorang pejabat yang mendapat hadiah kemungkinan besar akan mempengaruhi keputusan atau kebijakannya terhadap si pemberi hadiah. Karena itulah, setiap pemberian hadiah (gratifikasi) dalam batasan jumlah tertentu harus dikembalikan ke kas negara oleh pihak KPK.

\section{Pendekatan dhariah pada UU RI Nomor 23 Tahun 2002 tentang Perlindungan Anak}

Komitmen negara untuk melindungi warga negaranya, termasuk di dalamnya anak-anak, dapat ditemukan dalam Pembukaan Undang-Undang Dasar 1945 (UUD 1945), alinea keempat yang berbunyi: "Kemudian dari pada itu, untuk membentuk suatu pemerintahan negara Indonesia yang melindungi segenap bangsa Indonesia ...”.Selanjutnya dijabarkan dalam pasal-pasal Batang Tubuh UUD 1945. Pasal yang secara eksplisit menyatakan hak anak, hanya Pasal 28 B ayat (2) tersebut yang menyebutkan adanya hak asasi anak, tetapi keseluruhan pasal-pasal UUD 1945 yang memuat hak-hak setiap orang, sepanjang dapat dilaksanakan dan dapat diterima, serta bermanfaat bagi anak, maka hak-hak yang dimaksud harus dialamatkan juga kepada anak dan bukan monopoli manusia dewasa (Waluyadi, 2009:1-2).

Amandemen II (18 Agustus 2000) merupakan perubahan yang signifikan terhadap UUD 1945, yaitu dicantumkannya bab tersendiri tentang Hak Asasi Manusia, bahkan secara khusus juga tercantum hak asasi anak. Hal ini mungkin dilatarbelakangi oleh pengaruh globalisasi yang pada akhir abad XX mendengung-dengungkan Hak Asasi Manusia dengan lebih nyaring (Manan,2009:32).

Menurut Maidin Gultom (2008:33), perlindungan anak adalah segala usaha yang dilakukan untuk menciptakan kondisi agar setiap anak dapat melaksanakan hak dan kewajibannya, 
demi perkembangan dan pertumbuhan anak secara wajar, baik fisik, mental, dan sosial. Perlindungan anak merupakan perwujudan keadilan dalam suatu masyarakat.

Barda Nawawi sebagaimana dikutip oleh Waluyadi (2009:1), menyatakan bahwa perlindungan hukum bagi anak dapat diartikan sebagai upaya perlindungan hukum terhadap berbagai kebebasan dan hak asasi anak (fundamental rights and freedom of children), serta berbagai kepentingan yang berhubungan dengan kesejahteraan anak. Jadi, masalah perlindungan hukum bagi anak mencakup lingkup yang sangat luas.

Undang-Undang yang terakhir dan secara spesifik berbicara tentang perlindungan anak adalah Undang-Undang Nomor 23 Tahun 2002 tentang Perlindungan Anak. Sebagai UndangUndang yang terakhir disahkan dan secara spesifik mengatur tentang perlindungan anak, rumusan dan ketentuan yang berkaitan dengan perlindungan anak, lebih lengkap dan sempurna dibandingkan dengan peraturan perundang-undangan yang sebelumnya. Selain istilah perlindungan anak, Undang-Undang ini juga menyebut istilah "kuasa asuh" yang diartikan sebagai kekuasaan orang tua untuk mengasuh, mendidik, memelihara, membina, melindungi, dan menumbuh kembangkan anak, sesuai dengan agama yang dianutnya dan kemampuan, bakat, serta minatnya.

Selanjutnya, pada Bagian Keempat tentang Kewajiban dan Tanggung Jawab Keluarga dan Orang Tua, Pasal 26 dinyatakan bahwa orang tua berkewajiban dan bertanggung jawab untuk: a) mengasuh, memelihara, mendidik, dan melindungi anak; b) menumbuh kembangkan anak sesuai dengan kemampuan, bakat, dan minatnya; dan c) mencegah terjadinya perkawinan pada usia anak-anak. Penerapan konsep sadd al-dhariah antara lain larangan melanggar amanah bagi pemerintah dalam melaksankan UU. No. 23 Tahun 2002 tentang perlindungan anak; larangan bagi orang tua melalaikan kewajiban terhadap anak; larangan menelantarkan anak; larangan berkata "ah" kepada orangtua. Sedangkan fat kewajiban dan tanggung jawab keluarga dari orangtua

Prinsip perlindungan anak dalam CRC (Convention on the Rights of the Child) dijumpai 4 prinsip dasar, yaitu: non-discrimination (non diskriminasi); the best interest of child (kepentingan yang terbaik bagi anak); right of survival, develop andparticipation (hak untuk hidup, kelangsungan hidup, dan perkembangan), dan recognition for free expression (penghargaan terhadap pendapat anak). 
ljtihad, Jurnal Wacana Hukum Islam dan Kemanusiaan, Volume 16, №. 1, Juni 2016: 105-129

Pertama, non-discrimination adalah penyelenggaraan perlindungan anak yang bebas dari bentuk apapun tanpa memandang etnis, agama, keyakinan politik, dan pendapat-pendapat lain, kebangsaan, jenis kelamin, ekonomi (kekayaan, ketidakkemampuan), keluarga, bahasa dan kelahiran serta kedudukan dari anak dalam status keluarga. Dalam pasal 13 dan 77 UU Nomor 23 tahun 2002 tentang Perlindungan Anak ditegaskan bahwa perlindungan anak dari diskriminasi adalah hak yang dilindungi hukum dan bagi yang melanggar hak tersebut dipidana, khususnya dalam bidang pengasuhan anak. Non-diskriminasi ditemukan pula dalam al-Qur'an terdapat larangan tindakan diskriminatif pada anak.

Sadd dzariah dari non-diskriminasi antaralain melanggar hak asuh anak.; larangan membedakan latarbelakang etnis, bangsa, jenis kelamin dan kekayaan dalam memberi perlindungan terhadap anak. Fath dzariah dari non-diskriminasi antaralain persamaan hak terhadap hak asuh anak.

Kedua, the best of interest of child bahwa dalam semua tindakan yang menyangkut anak yang dilakukan oleh pemerintah, masyarakat, badan legislatif, dan badan yudikatif, maka kepentingan yang terbaik bagi anak harus menjadi pertimbangan utama. Dalam sejarah Islam baik pada masa Nabi Muhammad Saw. maupun KhulafaurraShidin terdapat banyak peristiwa yang menggambarkan pemihakan Islam terhadap anak bila terjadi peristiwa keluarga yang terkait dengan status dan kepentingan anak. Diantaranya dalam hal dimana orang tua diberi kesempatan untuk mengelola harta anak, namun dalam perjalanannya cenderung merugikan anak. Sadd al-dhariah dari the best of interest of child larangan mengambil sesuatu yang dibutuhkan anak sehingga tidak memberatkan dan membahayakan bagi anak. Fath aldhariah dari the best of interest of child mendahulukan kebutuhan aruriyah (necesity/niscaya) anak, di antaranya hak nafkah dan hak mendapatkan pendidikan yang layak.

Ketiga, survival and development of child; Asas hak untuk hidup, kelangsungan hidup, dan perkembangan adalah hak asasi yang paling mendasar bagi anak yang dilindungi oleh negara, pemerintah masyarakat, keluarga, dan orang tua. Dalam ajaran Islam anak adalah bukan saja anugerah Allah, tetapi juga adalah amanah. Islam memandang bahwa Anak memiliki hak tumbuh kembang dan hak hidup yang mendasar. Sadd al-dhariah dari Survival and Development of Child adalah larangan menyia-nyiakan hak untuk hidup, kelangsungan hidup anak karena merupakan hak paling mendasar bagi anak. Fath al-dhariah dari Survival and Develop- 
ment of Child pelaksanaan amanah dari orangtua dan hak hidup anak.

Keempat, Recognition for free expression artinya penghargaan terhadap pendapat anak, yang dimaksud dengan prinsip ini adalah penghormatan atas hak-hak anak untuk berpartisipasi dan menyatakan pendapatnya dalam pengambilan keputusan terutama jika menyangkut hal-hal yang mempengaruhi kehidupannya dan mainan yang dikehendaki.

Nabi adalah menampilkan kearifan dalam memperlakukan anak. Misalnya, ketika terjadi perbedaan pendapat dengan anak-anak beliau memperlakukan secara bijaksana dengan menggunakan kata-kata "fasabrun alaibinna (sabarlah terhadap mereka)". Kemudian "faabsin suḅbatabunna" (bergaulah dengan baik sesama mereka). Al-Ghazali menyarankan, bahwa janganlah memperbanyak ucapan mencela anak karena hal tersebut akan membuat anak meremehkan celaan, yang pada gilirannya akan membuat anak tidak menghargai nasehatnasehat orang tua. Sadd al-dhari'ah dari Survival and Development of Child, larangan orangtua untuk tidak mendikte dan tidak mencela terhadap perbuatan anak.

UU RI Nomor 23 Tahun 2002 tentang Perlindungan Anak sesungguhnya merupakan upaya melindungi anak Indonesia dari perlakuan yang sewenang-wenang. Namun, eksistensinya seringkali dijadikan "alat" untuk menjustifikasi kesalahan anak. Kondisi ini berdampak semakin sulitnya guru melaksanakan tugas kependidikan untuk menegakkan kedisiplinan, terutama membina kepribadian anak dengan akhlak yang terpuji.

Perlakuan terhadap guru, sebagai tenaga pendidik, seringkali berada pada posisi yang dilematis, antara tuntutan profesi dan perlakukan masyarakat. Mereka dituntut untuk mampu menghantarkan peserta didik mencapai tujuan pendidikan dan berupaya untuk menegakkan kedisplinan. Konsep sadd al-dhari ${ }^{\prime}$ h pada perlindungan guru merupakan upaya mrmberikan perlidungan terhadap anak.

Urgensi UU Guru dan Dosen, secara yuridis, UU Perlindungan Guru dan Dosen telah termuat dalam UU No 14/2005. Hal ini terlihat jelas pada Bab VII pasal 39 yang menyebutkan bahwa Pemerintah, masyarakat, organisasi profesi, dan/atau satuan pendidikan wajib memberikan perlindungan terhadap guru dalam pelaksanaan tugas. Adapun maksud Perlindungan Profesi yang diamanatkan dalam UU No 14/2005 tentang Guru dan Dosen adalah perlindungan terhadap Pemutusan Hubungan Kerja (PHK) yang tidak sesuai dengan peraturan dan perundang-undangan yang berlaku, pemberian imbalan yang tidak wajar, 
ljtihad, Jurnal Wacana Hukum Islam dan Kemanusiaan, Volume 16, №. 1, Juni 2016: 105-129

pembatasan dalam menyampaikan pandangan, pelecehan terhadap profesi, dan pembatasan/ pelarangan lain yang dapat menghambat guru dalam melaksanakan tugasnya. Sementara perlindungan keselamatan dan kesehatan kerja meliputi perlindungan terhadap risiko gangguan keamanan kerja, kecelakaan kerja, kesehatan, dan resiko lainnya. Perlindungan terhadap guru adalah sadd al-dhari'ah karena upaya mencegah kenakalan siswa dan penegakan disiplin siswa.

Memukul anak dengan cara yang benar, merupakan bagian dari sadd al-dhari' ${ }^{\prime} a h$. Hukum Islam tidak hanya mengatur tentang perilaku manusia yang sudah dewasa, tetapi juga yang belum dewasa. Hal ini bukan berarti bahwa hukum Islam cenderung mengekang kebebasan manusia. Tetapi karena memang salah satu tujuan hukum Islam adalah untuk mewujudkan kemaslahatan dan menghindari kerusakan (mafsadab).

\section{Paradigma baru hukum perlindungan anak pasca perubahan undang-undang perlindungan anak}

Anak adalah bagian yang tidak terpisahkan dari keberlangsungan hidup manusia dan keberlangsungan sebuah bangsa dan negara. Agar kelak mampu bertanggung jawab dalam keberlangsungan bangsa dan negara, setiap anak perlu mendapat perlindungan dan kesempatan yang seluas-luasnya untuk tumbuh dan berkembang secara optimal baik fisik, mental, maupun sosial.

Dalam hal menjamin seorang anak agar kehidupannya bisa berjalan dengan normal, maka negara telah memberikan payung hukum yakni Undang-Undang Nomor 23 Tahun 2002 tentang Perlindungan Anak. Namun kenyataannya undang-undang tersebut dirasa belum dapat berjalan secara efektif karena masih adanya tumpang tindih antar peraturan perundangundangan sektoral terkait dengan definisi anak, di sisi lain maraknya kejahatan terhadap anak di tengah-tengah masyarakat, salah satunya adalah kejahatan seksual yang saat ini banyak dilakukan oleh orang-orang dekat sang anak, serta belum terakomodirnya perlindungan hukum terhadap anak penyandang disabilitas.

Undang-Undang Nomor 23 Tahun 2002 tentang Perlindungan Anak yang saat ini sudah berlaku \pm (kurang lebih) 12 (dua belas) tahun akhirnya diubah dengan paradigma UndangUndang Nomor 35 Tahun 2014 tentang Perubahan Atas Undang-Undang Nomor 23 Tahun 2002 tentang Perlindungan Anak, yang mempertegas tentang perlunya pemberatan sanksi 
pidana dan denda bagi pelaku kejahatan terhadap anak terutama kepada kejahatan seksual yang bertujuan untuk memberikan efek jera, serta mendorong adanya langkah konkrit untuk memulihkan kembali fisik, psikis dan sosial anak. Hal tersebut perlu dilakukan untuk mengantisipasi anak (korban kejahatan) dikemudian hari tidak menjadi pelaku kejahatan yang sama. Karena berdasarkan fakta yang terungkap pada saat pelaku kejahatan terhadap anak (terutama pelaku kejahatan seksual) diperiksa di persidangan, ternyata sang pelaku dulunya juga pernah mengalami (pelecehan seksual) sewaktu sang pelaku masih berusia anak, sehingga sang pelaku terobsesi untuk melakukan hal yang sama sebagaimana yang pernah dialami.

Undang-Undang Nomor 35 Tahun 2014 yang mulai efektif berlaku pertanggal 18 Oktober 2014 banyak mengalami perubahan "paradigma hukum”, diantaranya memberikan tanggung jawab dan kewajiban kepada negara, pemerintah, pemerintah daerah, masyarakat, keluarga dan orang tua atau wali dalam hal penyelenggaran perlindungan anak, serta dinaikannya ketentuan pidana minimal bagi pelaku kejahatan seksual terhadap anak, serta diperkenalkannya sistem hukum baru yakni adanya hak restitusi.

\section{Tanggung jawab negara, pemerintah, orang tua dan masyarakat dalam perlindungan anak}

Mengenai tanggung jawab negara, pemerintah dan pemerintah daerah dalam UndangUndang Nomor 35 Tahun 2014 diatur dalam beberapa pasal yang diantaranya mewajibkan dan memberikan tanggung jawab untuk menghormati pemenuhan hak anak tanpa membedakan suku, agama, ras, golongan, jenis kelamin, etnik, budaya dan bahasa, status hukum, urutan kelahiran, dan kondisi fisik dan/atau mental, serta melindungi, dan menghormati hak anak dan bertanggung jawab dalam merumuskan dan melaksanakan kebijakan di bidang penyelenggaraan perlindungan anak. Pemerintah daerah berkewajiban dan bertanggung jawab untuk melaksanakan dan mendukung kebijakan nasional dalam penyelenggaraan perlindungan anak di daerah yang dapat diwujudkan melalui upaya daerah membangun kabupaten/kota layak anak, serta memberikan dukungan sarana, prasarana, dan ketersediaan sumber daya manusia dalam penyelenggaraan perlindungan anak.

Fatḥ al-dhari'ah dalam pelaksanaan tanggungjawab terlihat dari kewajiban dan memberikan tanggung jawab untuk menghormati pemenuhan hak anak. Penerapan sadd 
ljtihad, Jurnal Wacana Hukum Islam dan Kemanusiaan, Volume 16, №. 1, Juni 2016: 105-129

al-dhari'ah dapat dilihat bahwa semua fihak tidak boleh lagi berpangku tangan dan bermasa bodoh dalam hal perlindungan kepada anak.

\section{Kejahatan Seksual terhadap Anak}

Berdasarkan data Komnas Perlindungan Anak (KPA), laporan kekerasan terhadap anak pada tahun 2011 mencapai 2.509 kasus, dengan 52 persen diantaranya merupakan kategori kekerasan seksual terhadap anak. Tahun 2012, kekerasan terhadap anak bukannya menurun, malah meningkat, yaitu laporan kekerasan terhadap anak naik menjadi 2.637, dengan presentasi 62 persen merupakan kekerasan seksual diantaranya kategori pelecehan seksual sebanyak 122 kasus. Untuk tahun ini saja, sampai tanggal 23 Februari 2013 Komnas Perlindungan Anak (PA) sudah menerima 80 laporan diantaranya merupakan kekerasan seksual kepada anak-anak yang dilakukan oleh orang dewasa atau orang terdekat (Sirait: 2013).

Kasus tentang pelecehan seksual terhadap anak dimana pelakunya adalah orang dewasa dan kebanyakan adalah yang telah dikenal korban. Cerita tentang dukun cabul di Cirebon, dimana korbannya adalah gadis-gadis ABG (anak baru gede) yang rata-rata berumur 12 (dua belas) hingga 14 (empat belas) tahun. Cerita guru yang memperkosa muridnya yang terjadi di Buleleng, Bali, kasus Edy Afhan (14 tahun) yang bersetubuh dengan Meka (3 tahun). Pemerkosaan siswi SMP di Bengkulu pada hari Sabtu 2 April 2016. Yuyun siswi kelas VIII SMP di Kecamatan Padang Ulak Tanding (PUT), Kabupaten Rejang Lebong, Provinsi Bengkulu dibunuh kemudian diperkosa oleh 14 orang yang diduga keras sudah dikenal oleh korban. Terakhir, peristiwa pemerkosaan dan pembunuhan anak berumur 10 tahun berinisial MN di Kecamatan Labuhan Ratu, Kabupaten Lampung Timur (Lamtim) pada 14 April lalu. Diduga keras pelakukanya yang berjumlah 10 orang sudah dikenal juga oleh korban. Jadi sangat beralasan kalau kemudian kondisi ini menghadirkan wacana darurat perlindungan anak.

Aktifitas seksual anak remaja yang menyimpang sangat memprihatinkan karena telah mengarah pada tindak kriminal, (Kartono, 1992:8) Berkaitan dengan kriteria anak nakal yang melakukan tindak pidana maka si anak telah mencapai umur 8 (delapan) tahun ini belum mencapai umur 18 (delapan belas) tahun dan belum menikah (pasal 1(2) UU No. 3 
tahun 1997). Selain itu, dalam KUHP pasal 45 menyatakan, bahwa yang belum dewasa adalah anak yang belum berumur 16 (enam belas) tahun. Sedang berkaitan dengan anak yang menjadi korban pidana, KUHP mengatur umur anak adalah belum genap 15 (lima belas) tahun (Prinst, 1997:3).

Dalam Hukum Islam ada beberapa pendapat tentang batasan seorang anak yang dapat dikenakan pertanggungjawaban pidana. Menurut kebanyakan Fuqaha, mereka membatasi usia seorang anak yang dapat dikenai pertanggungjawaban pidana atas jarimab yang diperbuatnya yaitu setelah si anak mencapai usia 15 tahun. Sedang menurut Ahmad Hanafi yang mengutip Imam Abu Hanifah, membatasi kedewasaan pada usia 18 tahun dan menurut satu riwayat 19 tahun (Hanafi, 1976:370).

Islam menanamkan dan memegang teguh prinsip kesamaan dihadapan hukum dan perlindungan hukum tanpa diskriminasi dengan begitu jelas dan tegas. Para hakim ditugaskan untuk menjalankan tugasnya dengan adil dan tidak berpihak (Santosa, 2001:103). Namun begitu, seorang hakim harus memperhatikan kemampuan pertanggunganjawaban pidana pelaku kejahatan dalam menjatuhkan hukuman, dan jangan ada keraguan dalam menjatuhkan hukuman karena hal itu dapat menjadi sebab gugurnya hukuman (Sayyid Sabiq, 1993:3). Bagaimanapun suatu kejahatan harus mendapat imbalan atau hukuman yang sepantasnya karena hukuman selain dapat dijadikan suatu balasan atas tindak kejahatan dapat juga sebagai perbaikan dan pencegahan akan semakin maraknya tindak kejahatan.

Dalam undang-undang perlindungan anak yang lama ancaman pelaku kejahatan seksual hanya diancam dengan pidana maksimal 15 (lima belas) tahun, minimal 3 (tiga) tahun dan denda maksimal Rp300.000.000,- (tiga ratus juta rupiah) dan minimal Rp60.000.000,- (enam puluh juta rupiah), sedangkan dalam Undang-Undang Nomor 35 Tahun 2014 diubah dengan ancaman pidana maksimal 15 (lima belas) tahun, minimal 5 (lima) tahun dan denda maksimal sebanyak Rp5.000.000.000,- (lima milyar rupiah). Yang lebih khusus dalam undang undang ini adalah jika pelaku pemerkosaan atau pencabulan dilakukan oleh orang tua, wali, pengasuh anak, pendidik, atau tenaga pendidik maka pidananya ditambah $1 / 3$ (sepertiga).

Perubahan ancaman pidana maksimal 15 (lima belas) tahun, minimal 3 (tiga) tahun dan denda maksimal Rp300.000.000,- (tiga ratus juta rupiah) dan minimal Rp60.000.000,- (enam puluh juta rupiah), dengan ancaman pidana maksimal 15 (lima belas) tahun, minimal 5 (lima) 
ljtihad, Jurnal Wacana Hukum Islam dan Kemanusiaan, Volume 16, №. 1, Juni 2016: 105-129

tahun dan denda maksimal sebanyak Rp5.000.000.000,- (lima milyar rupiah). Adalah sadd aldhariah karena akan meminimalisisir kejahatan seksual dan membuat jera pelaku serta terlaksananya perlindungan anak terhadap kejahatan seksual. Apalagi ketika pelaku adalah pembimbing atau pendukung perlindungan maka tepat secara sadd al-dhariah jika pelaku pemerkosaan atau pencabulan dilakukan oleh orang tua, wali, pengasuh anak, pendidik, atau tenaga pendidik maka pidananya ditambah $1 / 3$ (sepertiga).

\section{Restitusi}

Hal baru dalam sistem pemidanaan kita di Indonesia adalah adanya hak restitusi dalam undang-undang ini. Menurut Peraturan Pemerintah Nomor 3 Tahun 2002 tentang Kompensasi, Restitusi, dan Rehabilitasi Terhadap Korban Pelanggaran Hak Asasi Manusia yang Berat, restitusi adalah ganti kerugian yang diberikan kepada korban atau keluarganya oleh pelaku atau pihak ketiga, dapat berupa pengembalian harta milik, pembayaran ganti kerugian untuk kehilangan atau penderitaan, atau penggantian biaya untuk tindakan tertentu.

Berdasarkan gambaran tersebut di atas tentu kita sudah faham bahwa yang dimaksud dengan restitusi adalah adanya ganti rugi kepada korban. Dalam Undang-Undang Nomor 35 Tahun 2014 masalah restitusi hanya di atur dalam satu pasal yakni pada Pasal 71 D yang menyebutkan bahwa:

(1) Setiap Anak yang menjadi korban sebagaimana dimaksud dalam Pasal 59 ayat (2) buruf b, buruf $d$, buruff, buruf h, huruf $i$, dan huruf j berhak mengajukan ke pengadilan berupa bake atas restitusi yang menjadi tanggung jawab pelaku kejahatan;

(2) Ketentuan lebih lanjut mengenai pelaksanaan restitusi sebagaimana dimaksud pada ayat (1) diatur dengan peraturan pemerintah.

Pasal 59 berbunyi :

(1) Pemerintah, Pemerintah Daerah, dan lembaga negara lainnya berkewajiban dan bertanggung jawab untuk memberikan Perlindungan Khusus kepada Anak.

(2) Perlindungan Khusus kepada Anak sebagaimana dimaksud pada ayat (1) diberikan kepada: a. Anak dalam situasi darurat; b. Anak yang berhadapan dengan hukum; c. Anak dari kelompok minoritas dan terisolasi; d. Anak yang dieksploitasi secara ekonomi dan/atau seksual; e. Anak yang menjadi korban penyalahgunaan narkotika, 
alkohol, psikotropika, dan zat adiktif lainnya; f.Anak yang menjadi korban pornografi; g. Anak dengan IV/AIDS; h. Anak korban penculikan, penjualan, dan/ atau perdagangan; i. Anak korban Kekerasan fisik dan/atau psikis; j. Anak korban kejahatan seksual; k. Anak korban jaringan terorisme; Anak Penyandang Disabilitas; m. Anak korban perlakuan salah dan penelantaran; n. Anak dengan perilaku sosial menyimpang; dan o. Anak yang menjadi korban stigmatisasi dari pelabelan terkait dengan kondisi Orang Tuanya.

Dalam penjelasan pasal tersebut di atas yang dimaksud dengan "restitusi" adalah pembayaran ganti kerugian yang dibebankan kepada pelaku berdasarkan putusan pengadilan yang berkekuatan hukum tetap atas kerugian materiil dan/atau imateriil yang diderita korban atau ahli warisnya. Khusus untuk anak yang berhadapan dengan hukum yang berhak mendapatkan restitusi adalah anak korban.

Restitusi di negara-negara maju terutama di negara-negara Anglo Saxon seperti Inggris, Amerika Serikat, Australia dan New Zealand telah disahkan sebagai salah satu jenis pidana dalam peraturan perundang-undangannya. Karena itu, restitusi telah dapat diterapkan di negara-negara tersebut, dan yang paling awal melaksanakan adalah negara New Zealand mulai tahun 1963 (Schaper, 1968:117-118).

Penderitaan atau kerugian yang bersifat materil yang dialami oleh korban sebagai akibat dari perbuatan pidana yang dilakukan oleh orang lain, menurut Mardjono Reksodiputro (1994:77) sepantasnyalah pelaku perbuatan pidana (orang lain tersebut) yang menyediakan ganti rugi itu. Hal senada juga dinyatakan oleh Purwoto S. Gandasubrata, "Suatu perbuatan pidana yang melawan hukum tetapi tidak melanggar hak seseorang dan karenanya tidak menimbulkan kerugian nyata, cukup diberikan pidana (penjara) saja, sedangkan sebaliknya, barulah apabila perbuatan pidana ini melanggar hak dan menimbulkan kerugian, maka pantas dijatuhi ganti rugi (restitusi) (Gandasubrata, 1997-117).

Restitusi kepada korban kejahatan di dalam konteks hubungan pelaku dan korban, menurut Romli Atmasasmita (1992:44-45), merupakan suatu perwujudan dari resosialisasi tanggung jawab pelaku sebagai warga masyarakat. Melalui proses resosialisasi dimaksudkan dan diharapkan tertanam rasa tanggung jawab sosial dalam diri si pelaku, sehingga nilai restitusi dalam hal ini tidak terletak pada kemanjurannya membantu korban, namun berfungsi sebagai alat untuk lebih menyadarkan pelaku perbuatan pidana atas "hutangnya” (akibat perbuatannya) 
ljtihad, Jurnal Wacana Hukum Islam dan Kemanusiaan, Volume 16, №. 1, Juni 2016: 105-129

kepada korban.

L.H.C. Hulsman mengaitkannya dengan Asas subsidiaritas, yaitu pertama-tama alat kekuasaan negara yang bertugas menerapkan hukum pidana tidak sampai bergerak bilamana melalui suatu stelsel sanksi yang bersifat sosial dapat dicapai tujuan yang sama atau memang telah dicapai. Dengan lain perkataan bertentangan dengan undang-undang (juga hal yang bertentangan dengan undang-undang yang bersanksi pidana) sebanyak mungkin diusahakan untuk diselesaikan melalui cara-cara di luar hukum pidana (Saleh, 1984:21).

Pengaturan restitusi secara formal dalam bentuk peraturan perundang-undangan, baik di dalam ius constituendum (antara lain dalam Pasal 60 ke-4 tentang pembayaran ganti kerugian) maupun dalam ius constitutum (antara lain adalah Bab XIII Pasal 98-101 KUHAP tentang penggabungan perkara gugatan ganti kerugian),(Gandasubrata, 1977:118-119) serta juga dalam Undang-Undang Nomor 13 Tahun 2006 yang dalam hal ini membedakan dua jenis hak korban. Korban kejahatan "konvensional" yang ternyata tidak berhak atas bantuan medis dan bantuan rehabilitas psiko-sosial. Hak ini hanya diberikan kepada korban dalam pelanggaran hak asasi manusia yang berat. Di samping itu, korban dalam pelanggaran hak asasi manusia yang berat, melalui LPSK, berhak mengajukan kompensasi dan restitusi. Sedangkan korban kejahatan "konvensional” hanya berhak mengajukan restitusi saja.

Konsep restitusi ini adalah aplikasi dari fatḥ al-dhariah pada aspek kewajiban melaksanakan restitusi adalah jalan perlindungan bagi korban atau anak korban. Agar korban dan keluarganya mendapat ganti rugi atas masalah yang dialaminya.

Konsep ganti kerugian itu sebenarnya telah lama ada dan berlaku dalam hukum adat di Indonesia, dan beberapa waktu belakangan ini telah pula diperjuangkan sebuah pendekatan konsep yaitu melalui metode pendekatan keadilan restoratif. Istilah Keadilan restoratif biasanya disimbolkan ke Albert Eglash yang mencari perbedaan yang dia lihat antara 3 bentuk yang berbeda dari keadilan kriminal. Yang pertama adalah Keadilan retributif yang menitik beratkan pada menghukum pelaku atas apa yang mereka lakukan. Yang kedua berhubungan dengan apa yang dia sebut sebagai keadilan distributif yang menitik beratkan pada rehabilitasi pelaku. Yang ketiga adalah keadilan restoratif dimana dia secara luas menyeimbangkannya dengan prinsip-prinsip dasar penggantian kerugian. Mungkin dia adalah orang pertama yang menghubungkan istilah itu dengan pendekatan yang mencoba 
untuk menunjukan konsekuensi merugikan dari sebuah aksi pelaku pelanggaran, dengan mencari secara aktif melibatkan pelaku dan korban dalam proses yang ditujukan pada perbaikan untuk para korban dan rehabilitasi para pelaku. Angin baru dalam pembinaan narapidana dengan melandaskan diri pada teori restorasi mulai berhembus dan diterapkan. Inti dari teori ini adalah bahwa pemidanaan harus bertujuan untuk memulihkan hubungan pelaku dengan korbannya dan direstui oleh masyarakat.

\section{Penutup}

Pelaksanaan perlindungan anak dalam UU. No. 23 Tahun 2002 tentang perlindungan anak telah sesuai dengan konsep dhariah tetapi masih belum efektif menekan angka kekerasan terhadap anak. Penerapan konsep sadd al-dhariah antara lain larangan melanggar amanah bagi pemerintah dalam melaksankan UU. No. 23 Tahun 2002 tentang perlindungan anak; larangan bagi orang tua melalaikan kewajiban terhadap anak; larangan menelantarkan anak. Sedangkan fatḥ al-dhariah di antaranya pelaksanaan kewajiban dan tanggung jawab keluarga dari orangtua. Fath al-dhariah di terapkan pada pelaksanaan had \}anah di antaranya kuasa asuh orangtua untuk mengasuh, mendidik, memelihara, membina, melindungi dan menumbuhkembangkan anak. Sadd al-dhariah terlihat pada larangan bagi pemerintah dan orangtua menelantarkan anak dan melakukan kekerasan dalam keluarga (PKDRT). Dalam CRC (Convention on the Rights of the Child) dijumpai 4 prinsip dasar, sadd al-dhariah dari nondiskriminasi antaralain melanggar hak asuh anak.; larangan membedakan latarbelakang etnis, bangsa, jenis kelamin dan kekayaan dalam memberi perlindungan terhadap anak. Fath aldhariah dari non-diskriminasi antaralain persamaan hak terhadap hak asuh anak. Sadd al-dhariah dari the best of interest of child larangan mengambil sesuatu yang dibutuhkan anak sehingga tidak memberatkan dan membahayakan bagi anak. Fath al-dhariah dari the best of interest of child mendahulukan kebutuhan aruriyah (necesity) anak, di antaranya hak nafkah dan hak mendapatkan pendidikan yang layak. Sadd al-dhariah dari survival and development of Child adalah larangan menyia-nyiakan hak untuk hidup, kelangsungan hidup anak karena merupakan hak paling mendasar bagi anak. Fatḥ al-dhariah dari survival and development of Child pelaksanaan amanah dari orangtua dan hak hidup anak. Sadd al-dhariah dari survival and development of child, larangan orangtua untuk tidak mendikte dan tidak mencela terhadap perbuatan anak. 
ljtihad, Jurnal Wacana Hukum Islam dan Kemanusiaan, Volume 16, №. 1, Juni 2016: 105-129

Perubahan paradigma perlindungan hukum pada Undang-Undang Nomor 23 Tahun 2002 tentang Perlindungan Anak yang saat ini sudah berlaku \pm (kurang lebih) 12 (dua belas) tahun akhirnya diubah dengan Undang-Undang Nomor 35 Tahun 2014 tentang Perubahan atas Undang-Undang Nomor 23 Tahun 2002 tentang Perlindungan Anak, mulai efektif berlaku pertanggal 18 Oktober 2014. Perubahan paradigma hukum pada Undang-Undang Nomor 35 Tahun 2014 di antaranya, memberikan tanggung jawab dan kewajiban kepada negara, pemerintah, pemerintah daerah, masyarakat, keluarga dan orang tua atau wali dalam hal penyelenggaran perlindungan anak, serta dinaikannya ketentuan pidana minimal bagi pelaku kejahatan seksual terhadap anak, serta diperkenalkannya sistem hukum baru yakni adanya hak restitusi. Paradigma perubahan pada perlindungan anak mencerminkan pelaksanaan dhariah yang efektif untuk melindungi anak dari prilaku kekerasan seksual dan penyelenggaran perlindungan secara umum terhadap anak. Fatḥ al-dhariah dalam pelaksanaan tanggungjawab terlihat dari kewajiban dan memberikan tanggung jawab untuk menghormati pemenuhan hak anak. Penerapan sadd al-dhariah dapat dilihat bahwa semua fihak tidak boleh lagi berpangku tangan dan bermasa bodoh dalam hal perlindungan kepada anak. Perubahan ancaman pidana maksimal 15 (lima belas) tahun, minimal 3 (tiga) tahun dan denda maksimal Rp300.000.000,- (tiga ratus juta rupiah) dan minimal Rp60.000.000,- (enam puluh juta rupiah), dengan ancaman pidana maksimal 15 (lima belas) tahun, minimal 5 (lima) tahun dan denda maksimal sebanyak Rp5.000.000.000,- (lima milyar rupiah), adalah sadd aldhariah karena akan meminimalisisir kejahatan seksual dan membuat jera pelaku serta terlaksananya perlindungan anak terhadap kejahatan seksual. Apalagi ketika pelaku adalah pembimbing atau pendukung perlindungan maka tepat secara sadd al-dhariah jika pelaku pemerkosaan atau pencabulan dilakukan oleh orang tua, wali, pengasuh anak, pendidik, atau tenaga pendidik maka pidananya ditambah $1 / 3$ (sepertiga). Sadd al-dhariah, larangan untuk tidak membayar ganti rugi (kompensasi, restitusi dan rehabilitasi); larangan untuk tidak melanggar hak dan menimbulkan kerugian. Sedangkan penerapan pada fath al-dhariah pada aspek kewajiban melaksanakan restitusi adalah jalan perlindungan bagi korban atau anak korban. 


\section{Daftar pustaka}

Abd Al-Ghani Al-Ghanimi Ad-DimaShqi Al-Hanafi. Al-Lubāb Fi Sharh Al-Kitāb. Beirut: Dār Al-Ma'rifah, 1997.

Abdul Manan. Aspek-Aspek Pengubah Hukum. Jakarta: Kencana, 2009.

Abdul Wahab Khalaf. Ilm al-ușül al-fiqh. Mesir: Dār al-Hadits, 2003.

Abu Al-Faidh Muhammad Bin Muhammad Bin Abd Al-Razzaq (Al-Murtadha Al-Zabidi).

Tajj al-Arūs Fi Jawāhir Al-Qāmūs, Juz I, hlm. 5219 dalam Al-Maktabah Al-Shämilah, Versi 2.09.

Ahmad, Hanafi. Asas-Asas Hukum Pidana Islam. Jakarta: Bulan Bintang, 1976.

Ali Bin Ahmad Bin Sa’id Bin Ḥzm Al-Zhahiri. Al-Abkām Fi Ușül Al-Ibkām. Beirut: Dar AlKutub Al-'Ilmiyyah, 1998.

Ali Bin Ahmad Bin Sa'id Bin Hazm Al-Zhahiri. Al-Mahalli Bi Al-Āsār. Beirut: Dar Al-Kutub Al-Ilmiyah, 2003.

Ali bin Ahmad bin Sa’id bin Hazm azh-Zhahiri. Al-Abkām fi Ușūl al-Ihkām. Beirut: Dār alKutub al-Ilmiyyah, 1998.

Arist Merdeka Sirait, Ketua Umum Komnas Pa, Kekerasan Pada Anak Di Indonesia Http:/ /Nasional.News. Viva.Co.Id/News/Read/379793-Komnas-Pa_Kasus-KekerasanAnak-Naik, diakses Tanggal 6 Februari 2013,

Asmawi. Perbandingan Usul Fqih. Jakarta: Amzah: 2011.

Atmasasmita, Romli. "Masalah Santunan Terbadap Korban Tindak Pidana," dalam Majalah Hukum Nasional Departemen Kehakiman, 1992.

Gandasubrata, Purwoto S. "Masalah Ganti Rugi Dalam/Karena Perkara Pidana," Penegakan Hukum Dalam Mensukseskan Pembangunan, (Ed.) Badan Kontak Profesi Hukum Lampung. Bandung: Alumni, 1977.

Haroen, Nasrun. Ushul Figh 1. Jakarta: Logos, 1997.

Ibn Al-Qayyim Al-Jauziyyah. Aläm Al-Muwäqi'īn. Beirut: Dār Al-Kutub Al-'Ilmiyyah, 1996.

Ibrahim Bin Musa Al-Lakhmi Al-Gharnathi Al-Maliki (Al-Shathibi), Al-Muwâfaqat FÉ Ushûl Al-Fiqh, (Beirut: Dar Al-Ma'rifah, Tt.), h. Juz 3, h. 257-258.

Jalaluddin as-Suyuthi, al-AShbāh wa al-Ną̧hâir, Beirut: Dar al-Kutub al-Ilmiyyah, tt.

Kartini, Kartono. Patologi Sosial II (Kenakalan Remaja). Jakarta: CV. Rajawali, 1992.

Khun, Thomas S. The Structure Of Scientific Revolutions Alih Bahasa Tjun Surjaman Cet. II. Bandung: Pt. Remaja Rosdakarya, 1993.

M. Arief, Dikdik. Mansur dan Elisatris Gultom. Urgensi Perlindungan Korban Kejahatan Antara Norma dan Realitas. Jakarta: PT. Raja Grafindo Persada, 2007. 
ljtihad, Jurnal Wacana Hukum Islam dan Kemanusiaan, Volume 16, №. 1, Juni 2016: 105-129

Mahfudh, Sahal. Fikih Sosial: Upaya Pengembangan Madz̧ab Qauli dan Madz̧hab Manhaji. Pidato Promovendus pada Penerimaan Gelar Doktor Honoris Causa dalam Bidang Fikih Sosial di UIN Sharif Hidayatullah. Jakarta, 18 juni. Jakarta: Universitas Islam Negeri. Maliki, Elliwarti. Fiqh-Al-Mar'ah Perspektif Perempuan" dalam Http://www.Fatayat.or.id.

Muhammad Bin Ahmad Bin Abi Bakr Bin Farh Al-Qurthubi. Al-Jämi' Li Abkām Al-Qurān, Juz II, h. 56.

Muhammad Bin Ali Al-Shaukani. Irshād Al-Fubül FÉ Tahqīq Al-Haqq Min Ilm Al-Ushūl. Beirut: Dar Al-Kutub Al-Ilmiyyah, 1994.

Muhammad Bin Idris Al-Shafi'i. Al-Umm Juz VII. dalam Al-Marja' Al-Akbar Li At-Turäts Al-Islamiy. Shirkah Al-Aris, Tt.

Muhammad bin Ismail Abu Abdullah al-Bukhari al-Ja'fi. al-Jämi' as-Șahīh al-Mukhtashar. Beirut: Dar Ibn Katsir, 1987.

Muhammad Bin Ismail Abu Abdullah Al-Bukhari Al-Ju'fi. Al-Jāmi' As-Ṣahīh Al-Mukhtashar. Beirut: Dar Ibn Katsir, 1987.

Muhammad bin Mukarram bin Manzhur al-Afriqi al-Mishri. Lisān al-Arā̄. Beirut: Dār Șadir, tt.

Munawir, Ahmad Warson. Kamus al-Munawir. Surabaya: Pustaka Progessif, 1997.

Zuhri, M. dan Ahmad Qarib. Ilmu Ushul Fikih tejemahan kitab ilmu al-ushül al-fiqh. Semarang: Dina Utama, 1994.

Muslehuddin, Muhammad. Filsafat Hukum Islam dan Pemikiran Orientalis. Yogyakarta: Tiara Wacana, 1991.

Prinst, Darwan. Hukum Anak Indonesia. Bandung: Citra Aditya Bakti, 1997.

Sabiq, Sayyid. Fiqih Sunnah 9. Alih Bahasa M. Nabhan Husein. Bandung: Al-Ma'arif, 1995.

Saleh, Roeslan. Segi Lain Hukum Pidana. Jakarta: Ghalia Indonesia, 1984.

Santoso, Topo. Menggagas Hukum Pidana Islam. Bandung: ASh Shamil \& Grafindo, 2001.

Schafer, Stephen. The Victim And Criminal, Random House. New York, 1968.

Solihin, Lianny. Tindakan Kekerasan Terhadap Anak Dalam Keluarga dalam Http/ :Www.Google.Com.Id./2010/04. diakses 9 April 2016.

Yahya, Mukhtar dan Fatchurrahman. Dasar-dasar Pembinaan Hukum Islam: Fiqh Islami. Bandung: PT. Al-Ma'arif, 1986.

Zuhaili al-, Wahbah. Ushül al-Figh al-Islamiy. Damaskus: Dar al-Fikr, 1986.

Http:/ / Kessospedia.Blogspot.Com/2011/06/perlindungan-anak-dalam -islam/, Kesejabteraan Sosial Pedia Akses Tanggal 2-5-2015. 
Http://Id.Wikipedia.Org/Wiki/Wikipedia bahasa Indonesia, Paradigma di akses Tanggal 09 $05-2015$.

Uu Nomor 10 Tahun 2004 Tentang Pembentukan Peraturan Perundang-Undangan, Pasal 8.

Uu Nomor 23 Tahun 2002 Tentang Perlindungan Anak, Pasal 1, Angka 2.

Undang-Undang Nomor 13 Tahun 2006.

Minggu Pagi No. 52 Tahun 53 Minggu 1 April 2001.

X-File Edisi 91 Tahun II 18-24 Oktober 2001.

Tabloid Nova, Edisi No. 758/Xv Tanggal 8 September 2002.

\section{Program Komputer (Kitab Digital)}

Al-Marja' al-Akbar li at-Turäts al-Islämiy, Shirkah al-Aris li Kumbiutar, tt. Al-Maktabah al-Shämilah, versi 2.09. 